\title{
The distribution and removal of pharmaceutical contaminants in classic
}

\section{wastewater treatment process}

\author{
Hongbo Wang, Guorui Pang, Ning Ding, Pingping Jia, Ning Wang*
}

School of Municipal and Environmental Engineering, Shandong JianZhu University, Ji'nan, 250101, China

KEYWORDS: Municipal Wastewater, Pharmaceutical Contaminants, Removal ABSTRACT: The distribution of three typical pharmaceutical contaminants, caffeine, naproxen, and diclofenac was investigated in a typical municipal sewage treatment plant and the removal was analyzed in various treatment processes. The results show that all treatment units could affect the removal of pharmaceutical pollutants, of which, anaerobic tank, $\mathrm{A}^{2} \mathrm{O}$ biological treatment tank, and secondary clarifier had more effect than other units. It was found that activated sludge could adsorb and accumulate most of pharmaceutical contaminants.

\section{INTRODUCTION}

Pharmaceutical contaminants were widely found in waters as a class of persistent organic contaminants with pharmaceutical activities including antibiotics, anti-inflammatory drugs, steroids, antihypertensive drugs, contraceptives, hypnotics, diet pills, etc. The major sources of these could be hospital sewage, pharmaceutical, unmetabolized veterinary or human drugs in feces, and agriculture, animal husbandry and aquaculture waste (Guo \& Peng, 2007). Pharmaceutical contaminants threaten human health due to the high biological activity and bioaccumulation. For example, anti-inflammatory like dichlorobenzene sulfonamide could cause kidney dysfunction, contraceptive like ethinyl estradiol would result in estrogenic disorder (Triebskorn et al., 2004), cholesterol drugs like gemfibrozil may impair intracellular esterase, antibiotic like novobiocin and sulfadiazine could enhance lipid oxidation (Gagné, Blaise, Fournier, \& Hansen, 2006). Accumulation of these may cause rapid increase of cancer cell and growth retardation of renal and blood cell (Zhang, Geißen, \& Gal, 2008).

Due to the potential risk of pharmaceutical contaminants in natural waters, in 1990, the US Environmental Protection Agency investigated the surface waters for pharmaceutical contaminants, endocrine disruptors, and other emerging organic contaminants; and determined erythromycin, ibuprofen and other 24 kinds of pharmaceutical contaminants (Barnes et al., 2008). The United States has adopted the Federal Food, Drug, and Cosmetic Act and the National Environmental Policy Act for the emission control (Ternes \& Joss, 2006). In China, surface waters in many cities, to some extent, have been polluted by pharmaceutical contaminants and many researchers are working on the problem (Zhao et al., 2009).

In this work, Jinan No.1 and No.2 municipal sewage treatment plant were selected to investigate the pharmaceutical contaminants in each treatment unit and sludge dewatering. Three reported higher-concentration pharmaceutical contaminants, analgesic caffeine, anti-inflammatory naproxen, and non-steroidal anti-inflammatory diclofenac were chosen as target subjects, which were monitored along the whole treatment procedure and evaluated for the removal efficiency of each unit. 


\section{Materials and Methods}

\section{Materials}

All regents were purchased from sigma; caffeine solution standard substance $(0.50 \mathrm{mg} / \mathrm{L}$; $5 \mathrm{~mL} /$ branched, concentration $\geq 99 \%$ ), naproxen (solid, purity $\geq 98 \%$ ), diclofenac (solid, purity $\geq 98 \%$ ), HPLC grade methanol, and HPLC grade dichloromethane.

\section{Methods}

\section{Sample Collection}

Water samples and Sludge samples were collected in NO.1 and NO.2 wastewater treatment plants. Two sewage treatment plants used modified $\mathrm{A}^{2} \mathrm{O}$ process with the flow diagram and the sampling.

Water and sludge samples were collected on the same day, packaged and stored at $0-4^{\circ} \mathrm{C}$. Three batch samples were taken with an interval of 3 hours and mixed to eliminate the concentration fluctuation of the day. The water sample was $1 \mathrm{~L}$ and the sludge sample was $500 \mathrm{~g}$ before dewatering.

\section{Pretreatment}

\section{Water sample}

\section{Filtration}

First of all, the water sample was filtered serially with medium-speed filter paper and $0.45 \mu \mathrm{m}$ fiber membrane filter, avoiding clogging the SPE cartridges (C18 reversed phase extraction cartridges, US Supelco, Inc.). $\quad 3.5 \mathrm{~mol} / \mathrm{L}$ of hydrochloric acid was used to adjust the $\mathrm{pH}$ of the water sample to 2.5 , which was stored at $0-4^{\circ}$ C.to prevent adsorption by impurities or degradation of pharmaceutical substances.

\section{Solid phase extraction}

$1 \mathrm{~L}$ of water sample passed uniformly and continuously through the cartridge at a flowrate less than $5 \mathrm{~mL} / \mathrm{min}$ and followed the method described by (Koutsouba et al., 2003).

\section{Sludge sample}

The moisture of sludge sample was balanced naturally in a cool well-ventilated place for 3-4 days. Then the dry sludge was ground into powder $(<1 \mathrm{~mm})$ using a mortar. $30 \mathrm{~g}$ of the sample was wrapped with filter paper and placed in a Soxhlet extractor with $100 \mathrm{~mL}$ of acetone and $125 \mathrm{~mL}$ of methylene chloride as solvent and extracted for $36 \mathrm{hr}$ until the solution was dark brown. The extract was concentrated to approximately $5 \mathrm{~mL}$ using a rotary evaporator before purified with anhydrous sodium sulfate- alumina-silica gel column (Height: anhydrous sodium sulfate $1 \mathrm{~cm}$, alumina $6 \mathrm{~cm}$, silicone $12 \mathrm{~cm}$ ). Sequentially, the column was eluted with $10 \mathrm{~mL}$ of methylene chloride three times. The eluent was combined and concentrated to $1 \mathrm{~mL}$ with the rotary evaporator and nitrogen-blowing instrument before derivatized as the same process in above water sample pretreatment.

\section{Instrument analysis}

All samples were gas chromatography-mass spectrometry (Shimadzu Corporation GCMS-QP2010 Plus) equipped with DB-5MS capillary column $(60 \mathrm{~m} \times 0.32 \mathrm{~mm} \times 0.25 \mu \mathrm{m})$.

Chromatography conditions: for the temperature program setting, the initial temperature was $45^{\circ} \mathrm{C}$ and kept for $1 \mathrm{~min}$ before rose to $130^{\circ} \mathrm{C}$ at $45^{\circ} \mathrm{C} / \mathrm{min}$. Then the temperature reached to $180^{\circ} \mathrm{C}$ at $12{ }^{\circ} \mathrm{C} / \mathrm{min}$, to $240^{\circ} \mathrm{C}$ at $7^{\circ} \mathrm{C} / \mathrm{min}$, to $300^{\circ} \mathrm{C}$ at $12^{\circ} \mathrm{C} / \mathrm{min}$; inlet temperature was $290^{\circ} \mathrm{C}$, the injection volume was $1 \mu \mathrm{L}$, split injection ratio was 30: 1 , and the injection time was $1 \mathrm{~min}$; column inlet pressure was $76.1 \mathrm{kPa}$, column flow was $2.00 \mathrm{~mL} / \mathrm{min}$, the line speed was $38.0 \mathrm{~cm} / \mathrm{sec}$, the carrier gas was high purity helium, and the flowrate was $4.0 \mathrm{~mL} / \mathrm{min}$.

MS conditions: interface temperature was $250^{\circ} \mathrm{C}$, EI+bombardment source was used with the ion source temperature of $200^{\circ} \mathrm{C}$, and the sample was detected in selected ion monitoring mode (SIM) with the scan rate of $0.2 \mathrm{~s}$, mass range of 35-450 amu. 


\section{Standard curve}

$5 \mathrm{~mL}$ of $500 \mu \mathrm{g} / \mathrm{mL}$ caffeine standard solution was diluted with methanol to $10 \mu \mathrm{g} / \mathrm{mL}$ as standard stock solution and formulated to $0.03 \mu \mathrm{g} / \mathrm{mL}, 0.06 \mu \mathrm{g} / \mathrm{mL}, 0.1 \mu \mathrm{g} / \mathrm{mL}, 0.25 \mu \mathrm{g} / \mathrm{mL}, 0.50 \mu \mathrm{g} / \mathrm{mL}$ standard solutions.

$10 \mathrm{mg}$ of naproxen or diclofenac standard sample was dissolved in methanol and configured to $100 \mathrm{mg} / \mathrm{L}$ standard stock solution and formulated to $0.20 \mu \mathrm{g} / \mathrm{mL}, 0.40 \mu \mathrm{g} / \mathrm{mL}, 0.80 \mu \mathrm{g} / \mathrm{mL}, 1.00 \mu \mathrm{g} / \mathrm{mL}$, $2.00 \mu \mathrm{g} / \mathrm{mL}$ as standard solutions.

\section{RESULTS AND DISCUSSION}

The concentrations of three pharmaceutical pollutants from different units of two plants were shown in Table 1.

Table 1. Concentrations of Pharmaceutical pollutants in each outlet of No.1 wastewater treatment plant (ng/L)

\begin{tabular}{ccccccc}
\hline \multirow{2}{*}{ Effluent } & \multicolumn{3}{c}{ No.1 plant } & \multicolumn{3}{c}{ No.2 plant } \\
\cline { 2 - 7 } & Caffeine & $\begin{array}{c}\text { Naproxe } \\
\mathrm{n}\end{array}$ & $\begin{array}{c}\text { Diclofena } \\
\mathrm{c}\end{array}$ & $\begin{array}{c}\text { Caffeine } \\
\text { Naproxe }\end{array}$ & $\begin{array}{c}\text { Diclofena } \\
\mathrm{n}\end{array}$ \\
\hline Fine grille & 104.12 & 17.98 & 6.90 & 100.63 & 8.24 & 15.31 \\
Grit chamber & 107.53 & 18.52 & 6.56 & 103.43 & 9.03 & 13.4 \\
Anaerobic & 84.51 & 15.60 & 4.56 & 86.84 & 7.54 & 9.98 \\
AAO & 61.42 & 11.45 & 2.39 & 62.96 & 5.50 & 7.28 \\
Secondary settling & 33.40 & 9.58 & 1.71 & 36.88 & 4.33 & 5.19 \\
tank & & & & & & \\
Advanced treatment & 18.91 & 7.46 & 0.89 & 27.72 & 3.25 & 1.93 \\
UV-tank & 12.70 & 5.43 & 0.30 & 13.30 & 2.13 & 0.73 \\
\hline
\end{tabular}

The results show that caffeine was highest in raw sewage, followed by diclofenac and naproxen. The caffeine and naproxen concentrations in NO.1 wastewater treatment plant were higher than NO.2 while the diclofenac was lower, which could attribute to the different wastewater source in different communities the plants serviced. After grit chamber, the naproxen and caffeine concentrations increased, which might due to the structural characteristics of the pharmaceutical contaminants. Meanwhile the conjugated system is more stability than purine ring, making naproxen less polar than caffeine. However, diclofenac contains the chloride as an electron-accepting group and a methyl group as an electron-donating group, resulting in the central benzene ring shifting and polarizing, as well as an amino group and a carboxyl group taking the same effect. Since liposoluble substances (non-polar molecular) would enrich and adhere to inorganic particles, naproxen most likely to attach to sands, followed by caffeine while diclofenac not.

All three pharmaceutical contaminants degraded along the treatment process and the removal rates were shown in Table 2. 
Table 2. The removal rate of the pharmaceutical substance in each craft outlet of NO.1 wastewater treatment plant

\begin{tabular}{ccccccc}
\hline \multirow{2}{*}{ Effluent } & \multicolumn{3}{c}{ No.1 plant } & \multicolumn{3}{c}{ No.2 plant } \\
\cline { 2 - 7 } & Caffeine & $\begin{array}{c}\text { Naproxe } \\
\mathrm{n}\end{array}$ & $\begin{array}{c}\text { Diclofena } \\
\mathrm{c}\end{array}$ & Caffeine & $\begin{array}{c}\text { Naproxe } \\
\mathrm{n}\end{array}$ & $\begin{array}{c}\text { Diclofena } \\
\mathrm{c}\end{array}$ \\
\hline Grit Chamber & $-3.28 \%$ & $-3.00 \%$ & $4.93 \%$ & $-2.78 \%$ & $-9.59 \%$ & $12.48 \%$ \\
Anaerobic tank & $22.11 \%$ & $16.24 \%$ & $28.99 \%$ & $16.49 \%$ & $18.08 \%$ & $22.34 \%$ \\
AAO & $22.18 \%$ & $23.08 \%$ & $31.45 \%$ & $23.73 \%$ & $24.76 \%$ & $17.64 \%$ \\
$\begin{array}{c}\text { Secondary } \\
\text { settling tank }\end{array}$ & $26.91 \%$ & $10.40 \%$ & $9.86 \%$ & $25.92 \%$ & $14.20 \%$ & $13.65 \%$ \\
$\begin{array}{c}\text { Advanced } \\
\text { treatment }\end{array}$ & $13.92 \%$ & $11.79 \%$ & $11.88 \%$ & $9.10 \%$ & $13.11 \%$ & $21.29 \%$ \\
UV-tank & $5.96 \%$ & $11.29 \%$ & $8.55 \%$ & $14.33 \%$ & $13.59 \%$ & $7.84 \%$ \\
Total removal & $87.80 \%$ & $69.80 \%$ & $95.65 \%$ & $86.78 \%$ & $74.15 \%$ & $95.23 \%$ \\
\hline
\end{tabular}

The results represent that anaerobic tank, $\mathrm{A}^{2} \mathrm{O}$, and secondary settling tank could remove pharmaceutical contaminants efficiently. The removal rates of caffeine, naproxen, diclofenac were $22.11 \%, 16.24 \%$, and $28.99 \%$ in the anaerobic tank, respectively, $22.18 \%, 23.08 \%, 31.45 \%$ in the $\mathrm{A}^{2} \mathrm{O}$, and has reached $26.91 \%, 10.40 \%, 9.86 \%$ in the secondary settling tank.

Since pharmaceutical contaminants were removed primarily by biodegradation and sludge adsorption, the activated sludge was tested before dewatering and the results shown in Table 3.

Table 3. The concentration of pharmaceutical contaminants in activated sludge $(\mu \mathrm{g} / \mathrm{L})$

\begin{tabular}{cccc}
\hline \multirow{2}{*}{ Caffeine } & Jur & $\begin{array}{c}\text { NO. } \\
\text { plant }\end{array}$ & $\begin{array}{c}\text { NO.2 } \\
\text { plant }\end{array}$ \\
\hline & Jul & 3.24 & 3.02 \\
& Oct & 2.60 & 2.53 \\
& Apr & 0.14 & 0.12 \\
Naproxen & Jul & 0.17 & 0.13 \\
& Oct & 0.15 & 0.11 \\
Diclofena & Apr & 0.09 & 0.09 \\
c & Jul & 0.10 & 0.10 \\
& Oct & 0.10 & 0.09 \\
\hline
\end{tabular}

As shown in Table 3, pharmaceutical contaminants were enriched in the sludge. Owing to the highest concentration of caffeine in the water, it was also the highest in the sludge, followed by naproxen. Because of the poor fat solubility, diclofenac was the lowest in the sludge, matching the previous explanation.

\section{CONCLUSIONS}

The water samples were collected from the NO.1 and NO.2 wastewater treatment plants in Jinan and all influent contained certain concentrations of pharmaceutical contaminants 
(caffeine>naproxen>diclofenac). All individual treatment processes could remove pharmaceutical contaminants, especially for the anaerobic tank, $\mathrm{A}^{2} \mathrm{O}$ biological pond, and secondary settling tank. The analysis of activated sludge shows that pharmaceutical substances were adsorbed in the activated sludge and discharged into environment after dewatering. In addition, the content of caffeine in the water was more than 10ng/L, bringing a great threat to human health.

\section{REFERENCES}

Barnes, K. K., Kolpin, D. W., Furlong, E. T., Zaugg, S. D., Meyer, M. T., \& Barber, L. B. (2008). A national reconnaissance of pharmaceuticals and other organic wastewater contaminants in the United States-I) Groundwater. Science of the Total Environment, 402(2), 192-200.

Gagné, F., Blaise, C., Fournier, M., \& Hansen, P. D. (2006). Effects of selected pharmaceutical products on phagocytic activity in Elliptio complanata mussels. Comparative Biochemistry and Physiology Part C: Toxicology \& Pharmacology, 143(2), 179-186.

Guo, J., \& Peng, Y.-z. (2007). Research advances in removal and transformation of trace organic pollutants during wastewater treatment process. Modern Chemical Industry, 37(S1), 65-69.

Koutsouba, V., Heberer, T., Fuhrmann, B., Schmidt-Baumler, K., Tsipi, D., \& Hiskia, A. (2003). Determination of polar pharmaceuticals in sewage water of Greece by gas chromatography-mass spectrometry. Chemosphere, 51(2), 69-75.

Ternes, T. A., \& Joss, A. (2006). Human pharmaceuticals, hormones and fragrances. UK: IWA Publishing.

Triebskorn, R., Casper, H., Heyd, A., Eikemper, R., Köhler, H. R., \& Schwaiger, J. (2004). Toxic effects of the non-steroidal anti-inflammatory drug diclofenac: Part II. Cytological effects in liver, kidney, gills and intestine of rainbow trout (Oncorhynchus mykiss). Aquatic toxicology, 68(2), 151-166.

Zhang, Y., Geißen, S.-U., \& Gal, C. (2008). Carbamazepine and diclofenac: removal in wastewater treatment plants and occurrence in water bodies. Chemosphere, 73(8), 1151-1161. Zhao, J.-L., Ying, G.-G., Wang, L., Yang, J.-F., Yang, X.-B., Yang, L.-H., \& Li, X. (2009). Determination of phenolic endocrine disrupting chemicals and acidic pharmaceuticals in surface water of the Pearl Rivers in South China by gas chromatography-negative chemical ionization-mass spectrometry. Science of the Total Environment, 407(2), 962-974. 